\title{
Patenting DNA: Balancing the Need to Incentivize Innovation in Biotechnology with the Need to Make High-Quality Genetic Testing Accessible to Patients
}

\section{INTRODUCTION}

The issue of gene patentability implicates everyone from doctors, to patients, to biotechnology researchers, to holders of patents claiming genes of all kinds. Proponents of gene patents argue that patents are necessary for incentivizing innovation, commercializing valuable inventions, and promoting the disclosure of information for the benefit of the public, and that these objectives are particularly important in the biotechnology industry. Opponents of gene patents fear that the exclusive rights conferred by a patent restrict public access to medical treatments and diagnostic methods, which raises serious questions about the appropriate scope of such patents. These opposing positions spur the gene patent debate. To resolve this debate, the need to incentivize innovation must be balanced with the need to make medical testing and treatment readily available and affordable to the public.

This Comment argues that isolated genes are proper subjects for patent claims and should not be categorically excluded from patenteligible subject matter. Additionally, however, this Comment recognizes that gene patents raise legitimate concern about patient access to highquality genetic tests; therefore, Congress should enact certain research exemptions that would immunize researchers from infringement liability for performing noncommercial activities involving a patented gene. Part II.A discusses the purpose of the United States Patent Act and summarizes the subjects considered eligible for patent protection under current law. Part II.B briefly describes the science underlying gene patents and discusses gene patents in the context of an ongoing case, Association for Molecular Pathology v. United States Patent \&

* Jennifer Vogel. J.D. candidate 2013, University of Kansas School of Law; B.S. 2008, University of Notre Dame. 
Trademark Office. ${ }^{1} \quad$ Part II.C then explains opposing concerns surrounding gene patents, including the need to incentivize research, the need to make genetic testing available and affordable to patients, and the role that gene patents will likely play in whole genome sequencing. Part III.A emphasizes the importance of continuing to hold genes to be patent-eligible subject matter, while using the current requirements of patentability to invalidate claims undeserving of patent protection. Part III.B suggests solutions to the gene patent debate and examines the merits of each proposed solution. Finally, Part IV concludes that Congress should enact a statutory research exemption and cautiously consider alternative solutions like compulsory licensing or exercising march-in rights under the Bayh-Dole Act.

\section{BACKGROUND}

\section{A. United States Patent Law}

\section{Purpose of Patents}

The Constitution authorizes Congress to grant patents to "promote the Progress of Science and useful Arts." " A patent confers on an inventor "the right to exclude others from making, using, ... or selling [his] invention" for twenty years. ${ }^{3}$ Several justifications exist for granting these exclusive rights, although there is some disagreement over the validity of these theories. ${ }^{4}$ First, patent rights incentivize useful inventions by promising inventors and investors the opportunity to profit from their expended time, effort, and money. ${ }^{5}$ Second, patent rights incentivize the commercialization of inventions. ${ }^{6}$ Patents promote not only investments in research and development, but also the investments needed to make inventions commercially available for the benefit of the public. $^{7}$ And third, patent rights incentivize disclosure of inventions. ${ }^{8}$

1. Ass'n for Molecular Pathology v. U.S. Patent \& Trademark Office, 689 F.3d 1303 (Fed. Cir. 2012), aff'g in part, rev'g in part, 702 F. Supp. 2d 181 (S.D.N.Y. 2010), petition for cert. filed, Sept. 25, 2012.

2. U.S. Const. art. I, § 8, cl. 8.

3. 35 U.S.C. § 154(a) (2006).

4. See infra Part II.C.

5. Biotechnology Indus. Org. v. District of Columbia, 496 F.3d 1362, 1372 (Fed. Cir. 2007); see also 1 DONALD S. CHISUM, CHISUM ON PATENTS § 3.01, at 3-6 (2009).

6. See Mannington Mills, Inc. v. Congoleum Indus., 610 F.2d 1059, 1070 (3d Cir. 1979).

7. Id. 
Information disclosed in the patent becomes publicly available so that it may "stimulate further innovation and ... permit the public to practice the invention once the patent expires." "While patent rights are often couched in terms of rewarding an individual inventor's labor, ${ }^{10}$ their true purpose is to promote progress for the benefit of society. ${ }^{11}$ Indeed, the Constitution empowers Congress to grant patents because "encouragement of individual effort by personal gain is the best way to advance public welfare through the talents of ... inventors in 'Science and useful Arts. ${ }^{\prime 2}$

The biotechnology industry, where development of lifesaving therapies costs hundreds of millions of dollars, ${ }^{13}$ illustrates this need to incentivize individuals to invest their time and money in discoveries that ultimately benefit society. Patent rights enable an inventor to exclude others from making, using, or selling the patented invention, ${ }^{14}$ thereby allowing the inventor to recoup on the investment and realize a profit. ${ }^{15}$ The potential for profit drives researchers and investors to continue devoting resources to valuable innovations. ${ }^{16}$ While this is true in all industries, patent rights are particularly important to biotechnology companies, which rank patents as the most important means of securing a competitive advantage for their businesses. ${ }^{17}$

8. Aronson v. Quick Point Pencil Co., 440 U.S. 257, 262 (1979).

9. Id.

10. See, e.g., Mazer v. Stein, 347 U.S. 201, 219 (1954) ("Sacrificial days devoted to such creative activities deserve rewards commensurate with the services rendered.").

11. See United States v. Paramount Pictures, 334 U.S. 131, 158 (1948) ("[T]he patent statutes make[] reward to the [inventor] a secondary consideration.”).

12. Mazer, 347 U.S. at 219 (quoting U.S. ConST. art. I, § 8, cl. 8).

13. See Joseph A. DiMasi \& Henry G. Grabowski, The Cost of Biopharmaceutical R\&D: Is Biotech Different?, 28 MANAGERIAL \& DECISION ECON. 469, 477 (2007) (studying compoundspecific data to estimate the cost of biopharmaceutical research and development).

14. 35 U.S.C. § 154(a)(1) (2006).

15. See Biotechnology Indus. Org. v. District of Columbia, 496 F.3d 1362, 1372 (Fed. Cir. 2007) (discussing "pecuniary rewards stemming from the patent right"). 1995)).

16. Id. at 1372-73 (quoting King Instruments Corp. v. Perego, 65 F.3d 941, 950 (Fed. Cir.

17. See Stuart J.H. Graham et al., High Technology Entrepreneurs and the Patent System: Results of the 2008 Berkeley Patent Survey, 24 BERKELEY TECH. L.J. 1255, 1290 fig.1, 1290-91 (2009) (showing that the importance of patents varies by industry and summarizing survey results in which startup biotechnology firms ranked patents as their most important appropriability strategy). 
[Vol. 61

\section{Patent-Eligible Subject Matter and Patentability}

To be valid, a patent claim must first be directed to patent-eligible subject matter, ${ }^{18}$ and then must satisfy the additional requirements of utility, ${ }^{19}$ novelty, ${ }^{20}$ nonobviousness, ${ }^{21}$ and adequate disclosure. ${ }^{22}$ Thus, patent eligibility presents a threshold inquiry that must be resolved before a court turns to the other elements of patentability. ${ }^{23}$ Patent eligibility requires the subject matter of an invention to be the type of discovery that Congress intended to protect. $^{24}$ The scope of patenteligible subject matter is outlined in 35 U.S.C. $\S 101$, which provides that processes, machines, manufactures, and compositions of matter are proper subjects for patents. ${ }^{25}$

\section{a. "Anything Under the Sun That is Made by Man”}

The categories of patent-eligible subject matter have been broadly construed in accordance with "the constitutional and statutory goal of promoting 'the Progress of Science and the useful Arts.", 26 The Patent Act provides that a patent may be granted for "any new and useful process, machine, manufacture, or composition of matter." ${ }^{27}$ Congress need not authorize patent protection for specific subject matters; instead, courts determine whether the subject falls within one of the statutorily defined categories. ${ }^{28}$ Indeed, the Supreme Court has noted that Congress intended patent-eligible subject matter to "include anything under the sun

\footnotetext{
18. 35 U.S.C. § 101.

19. Id.

20. Id. § 102 .

21. Id. § 103(a).

22. Id. § 112 .

23. Bilski v. Kappos, 130 S. Ct. 3218, 3225 (2010). "The question here, as it always has been, is: are the inventions claimed of a kind contemplated by Congress as possibly patentable if they turn out to be new, useful, and unobvious ....” In re Bergy, 596 F.2d 952, 963-64 (C.C.P.A. 1979), vacated in part sub nom. Diamond v. Chakrabarty, 444 U.S. 1028 (1980), and aff'd sub nom. Diamond v. Chakrabarty, 447 U.S. 303 (1980).

24. See Parker v. Flook, 437 U.S. 584, 593 (1978).

25. 35 U.S.C. § 101.

26. Chakrabarty, 447 U.S. 303, 315 (1980) (quoting U.S. ConST. art. I, § 8, cl. 8).

27. 35 U.S.C. $\S 101$ (emphasis added); see also Chakrabarty, 447 U.S. at 308 ("In choosing such expansive terms as 'manufacture' and 'composition of matter,' modified by the comprehensive 'any,' Congress plainly contemplated that the patent laws would be given wide scope.” (quoting 35 U.S.C. § 101)).

28. See J.E.M. Ag Supply, Inc. v. Pioneer Hi-Bred Int'l, Inc., 534 U.S. 124, 130-31 (2001) (quoting Chakrabarty, 447 U.S. at 315).
} 
that is made by man."29 Even living organisms-from a genetically engineered bacterium $^{30}$ to plant breeds developed by humans ${ }^{31}$-are proper subjects for patents, provided they are the product of human intervention. ${ }^{32}$ The scope of the U.S. patent laws is necessarily broad, as to include scientific advances that were unforeseeable when Congress enacted $\S 101 .^{33}$

\section{b. Limitations on Patent-Eligible Subject Matter: Laws of Nature, Physical Phenomena, and Abstract Ideas}

Although courts have broadly construed the language of $\S 101$, the scope of patent-eligible subject matter is limited by three judicially created exceptions ${ }^{34}$ : "laws of nature, physical phenomena, and abstract ideas.”35 Although inventions or discoveries that fall within these excepted categories might properly be classified as patent-eligible processes or compositions of matter, they are not the type of invention that patents are intended to protect; ${ }^{36}$ rather, "they are the basic tools of scientific and technological work." improperly restrict further discovery. ${ }^{38}$ As such, a botanist could not patent a new plant discovered in the wild, nor could a physicist patent the law of gravity. ${ }^{39}$ Similarly, a scientist who discovers certain natural qualities of bacteria cannot obtain a patent on those qualities. ${ }^{40}$ These

29. Chakrabarty, 447 U.S. at 309 (quoting S. REP. No. 82-1979, at 5 (1952); H.R. REP. No. 821923, at 6 (1952)) (internal quotation marks omitted).

30. Id. at 310 .

31. J.E.M. Ag Supply, 534 U.S. at 145.

32. See Chakrabarty, 447 U.S. at 313 (finding that patent-eligible subject matter is that which is the result of human "ingenuity and research").

33. J.E.M. Ag Supply, 534 U.S. at 135.

34. Bilski v. Kappos, 130 S. Ct. 3218, 3225 (2010) (explaining that these exceptions are not statutory, but nonetheless, are clearly established under the doctrine of stare decisis and are consistent with the statutory requirements of novelty and utility).

35. Id. (quoting Chakrabarty, 447 U.S. at 309) (internal quotation marks omitted). These exceptions have also been characterized as "phenomena of nature, mental processes, and products of nature.” Ass'n for Molecular Pathology v. U.S. Patent \& Trademark Office, 653 F.3d 1329, 1349 (Fed. Cir. 2011) (citations omitted) (citing Gottschalk v. Benson, 409 U.S. 63, 67 (1972); Chakrabarty, 447 U.S. at 313), vacated sub nom. Ass'n for Molecular Pathology v. Myriad Genetics, Inc., 132 S. Ct. 1794 (2012).

36. See Parker v. Flook, 437 U.S. 584, 593 \& n.15 (1978).

37. Gottschalk, 409 U.S. at 67.

38. Mayo Collaborative Servs. v. Prometheus Labs., 132 S. Ct. 1289, 1301 (2012).

39. Chakrabarty, 447 U.S. at 309.

40. Funk Bros. Seed Co. v. Kalo Inoculant Co., 333 U.S. 127, 130 (1948). 
naturally occurring qualities are the work of nature. ${ }^{41}$ Such discoveries are "part of the storehouse of knowledge of all men ... free to all men and reserved exclusively to none." 42

These specific exceptions to patent-eligible subject matter have been well established for over 150 years, ${ }^{43}$ and the Supreme Court has thus far declined to carve out any additional exceptions. ${ }^{44}$ Rather, the requirements of utility, novelty, nonobviousness, and adequate disclosure should ensure that patent protection is not improperly afforded to a discovery or invention. ${ }^{45}$ Furthermore, the Court has cautioned lower courts against imposing bright-line limitations on patent-eligible subject matter, ${ }^{46}$ stating that a public-policy-based limitation on patent eligibility should come from Congress. ${ }^{47}$ Such a decision requires a "balancing of competing values and interests," which must be conducted by elected representatives, not courts. ${ }^{48}$ So for now, laws of nature, physical phenomena, and abstract ideas are the only subject matters expressly excluded from patent eligibility.

While a patent cannot claim one of these excepted categories, a patent may claim an application of a law of nature, physical phenomenon, or abstract idea to a structure or process. ${ }^{49}$ In other words, "a process is not unpatentable simply because it contains a law of

\section{Id.}

42. Bilski v. Kappos, 130 S. Ct. 3218, 3225 (2010) (alteration in original) (quoting Funk Bros. Seed Co., 333 U.S. at 130) (internal quotation marks omitted).

43. Id.

44. See Chakrabarty, 447 U.S. at 309-10, 316-17 (concluding that genetically engineered bacterium is patent-eligible subject matter because it does not fall within the natural phenomenon exception and refusing to establish a bright-line, policy-based rule against patenting living organisms). In Bilski, Justice Stevens, in a concurring opinion, advocated creating a bright-line rule excluding business methods from patent-eligible subject matter, but the majority declined to do so. 130 S. Ct. at 3232 (Stevens, J., concurring).

45. See Bilski, $130 \mathrm{~S}$. Ct. at 3226 (explaining that "[c]oncerns about attempts to call any form of human activity a 'process' can be met by making sure the claim meets the requirements of $\S 101$ ” instead of establishing an additional exception to patent eligibility).

46. See id. (cautioning that the existence of the three judicially created exceptions does not give "the Judiciary carte blanche to impose other limitations that are inconsistent with the text and the statute's purpose and design").

47. Chakrabarty, 447 U.S. at 317.

48. Id.

49. Diamond v. Diehr, 450 U.S. 175, 187-88 (1981) (citing Funk Bros. Seed Co. v. Kalo Inoculant Co., 333 U.S. 127 (1948); Eibel Process Co. v. Minn. \& Ont. Paper Co., 261 U.S. 45 (1923); Cochrane v. Deener, 94 U.S. 780 (1877); O’Reilly v. Morse, 56 U.S. 62 (1854); Le Roy v. Tatham, 55 U.S. 156 (1853)). 
nature[, physical phenomenon, or abstract idea]." ${ }^{\text {00 }}$ But "to transform an unpatentable law of nature into a patent-eligible application of such a law, one must do more than simply state the law of nature while adding the words "apply it." 51 The process must contain other elements exhibiting an "inventive concept," such that the claimed invention is much more than the law of nature, physical phenomenon, or abstract idea itself. $^{52}$ For example, the Arrhenius equation, which provides the cure time for rubber as a function of temperature, ${ }^{53}$ is a formula reflecting a law of nature and is therefore not patent-eligible subject matter. ${ }^{54}$ But a process for molding rubber that utilizes the Arrhenius equation is properly considered patent eligible. ${ }^{55}$ The process must still meet the other requirements for patentability, but at the very least, it satisfies the threshold inquiry. ${ }^{56}$ Essentially, an inventor may not claim the formula in the abstract; ${ }^{57}$ rather, he must claim use of the formula in conjunction with an inventive structure or process. ${ }^{58}$

\section{B. United States Patent Law in the Context of Gene Patents}

Until recently, § 101 has been a fairly dormant area of patent law. ${ }^{59}$ But a number of recent cases-including several involving gene patents-have changed that. Below is a brief explanation of the science underlying gene patents, followed by a discussion of recent litigation over gene patents, focusing on Association for Molecular Pathology v.

50. Id. at 187 (quoting Parker v. Flook, 437 U.S. 584, 590 (1978)) (internal quotation marks omitted).

51. Mayo Collaborative Servs. v. Prometheus Labs., 132 S. Ct. 1289, 1294 (2012) (citing Gottschalk v. Benson, 409 U.S. 63, 71-72 (1972)).

52. Id. (citing Parker, 437 U.S. at 594).

53. Diamond, 450 U.S. at 178 n.2.

54. Id. at 188 .

55. Id.

56. Id.

57. Id. at 191 (citing Gottschalk v. Benson, 409 U.S. 63 (1972)). A patent claim may not be directed to a formula in the abstract; this rule may not be avoided by directing the claim to use of the formula in a certain technological environment or by failing to claim significant post-solution activity. Id. at 191-92 (citing Parker, 437 U.S. 584).

58. Id. at 192.

59. See, e.g., Eileen M. Kane, Patent Ineligibility: Maintaining a Scientific Public Domain, 80 ST. JOHN's L. REV. 519, 519 (2006) (noting that patent eligibility has been a relatively dormant doctrine, resurfacing with the advent of new technologies and scientific imperatives). 
United States Patent \& Trademark Office. ${ }^{60}$ This discussion will help frame the controversy surrounding gene patents.

\section{Underlying Science}

The human genome contains approximately 22,000 genes. $^{61}$ Hereditary traits — such as eye color, hair color, height, weight, and even an increased risk of developing certain diseases-are dictated by genetics. ${ }^{62}$ Each gene is made up of DNA, and each DNA molecule is made up of a sequence of nucleotide bases. ${ }^{63}$ A gene's nucleotide sequence encodes for the amino acids that comprise a particular protein $;{ }^{64}$ for example, "the BRCA1 gene encodes for the BRCA1 protein." ${ }^{65}$ A mutation in a gene's sequence changes the structure and function of the protein encoded by that gene. ${ }^{66}$ In some cases, the effect of a mutation is serious, causing or increasing the risk of a particular disease. ${ }^{67}$ For example, mutations in the BRCA1 and BRCA2 genes are associated with a greater risk of developing breast and ovarian cancer. ${ }^{68}$ Women with BRCA mutations are four to six times more likely to develop breast cancer during their lifetimes than women without such mutations. ${ }^{69}$ Thus, genetic testing for these mutations is an important diagnostic tool. It allows patients to take precautionary measures, such as regular cancer screening or even prophylactic mastectomy, and also provides physicians with information relevant to cancer treatment plans, as cancers related to BRCA mutations are best treated by certain types of chemotherapy. $^{70}$

60. Ass'n for Molecular Pathology v. U.S. Patent \& Trademark Office, 689 F.3d 1303 (Fed. Cir. 2012), aff'g in part, rev'g in part, 702 F. Supp. 2d 181 (S.D.N.Y. 2010), petition for cert. filed, Sept. 25, 2012.

61. Id. at 1310 .

62. James D. WAtson et Al., Molecular Biology of the Gene 17 (5th ed. 2004).

63. Id. at 20-23, 28.

64. Id. at $35-36$.

65. Ass'n for Molecular Pathology v. U.S. Patent \& Trademark Office, 653 F.3d 1329, 1336 (Fed. Cir. 2011), vacated sub nom. Ass'n for Molecular Pathology v. Myriad Genetics, Inc., 132 S. Ct. 1794 (2012).

66. WATSON, supra note 62, at 470.

67. See id. For example, sickle cell anemia is caused by a genetic mutation. Id.

68. Ass'n for Molecular Pathology, 653 F.3d at 1339.

69. Id.

70. Id. 
A few key points will simplify the underlying science and facilitate a discussion of various issues raised by gene patents. First, the specific DNA sequence comprising a particular gene exists naturally in the human body as an integrated piece of a larger biological structure. ${ }^{71}$ An isolated gene is a sequence of DNA cleaved from surrounding genetic material and removed from its natural cellular environment. ${ }^{72}$ In this Comment, the term "gene patent" refers to a patent claiming an isolated gene (also referred to as an isolated sequence of DNA) or to a patent claiming a diagnostic method involving an isolated gene.

\section{Association for Molecular Pathology v. United States Patent \& Trademark Office}

The patentability of the BRCA genes is the issue in the ongoing case Association for Molecular Pathology v. United States Patent \& Trademark Office. ${ }^{73}$ There, a group of plaintiffs, comprised of various medical organizations, genetic researchers and counselors, and breast cancer and ovarian cancer patients, ${ }^{74}$ is suing Myriad Genetics asking the court to invalidate Myriad's patent claims to the BRCA genes on grounds that human genes are patent-ineligible subject matter. ${ }^{75}$ The challenged patent claims pertain to the isolated BRCA genes and diagnostic methods involving those genes. ${ }^{76}$ The district court agreed with the plaintiffs, holding that Myriad's claims were directed to patent-ineligible subject matter. ${ }^{77}$ However, the Federal Circuit reversed in part, holding that the composition claim to isolated DNA and one of the diagnostic method claims were directed to patent-eligible subject matter. ${ }^{78}$ The Supreme Court vacated the Federal Circuit's judgment and remanded the case for further consideration in light of a recent Court decision, Mayo

71. See WATSON, supra note 62, at 647 (describing the complexity of the living cell).

72. See id. at 647-72 (describing techniques for isolating and sequencing DNA).

73. Ass'n for Molecular Pathology v. U.S. Patent \& Trademark Office, 689 F.3d 1303 (Fed. Cir. 2012), aff'g in part, rev'g in part, 702 F. Supp. 2d 181 (S.D.N.Y. 2010), petition for cert. filed, Sept. 25, 2012.

74. Id. at 1308.

75. Id. at 1309 .

76. Id. at $1309-10$.

77. See id. at 1308 .

78. Ass'n for Molecular Pathology v. U.S. Patent \& Trademark Office, 653 F.3d 1329, 1334 (Fed. Cir. 2011), vacated sub nom. Ass'n for Molecular Pathology v. Myriad Genetics, Inc., 132 S. Ct. 1794 (2012). 
Collaborative Services v. Prometheus Laboratories. ${ }^{79}$ On remand, the Federal Circuit reaffirmed its earlier ruling upholding the composition claims and one method claim. ${ }^{80}$ The plaintiffs have filed a second petition for certiorari, again challenging the patent eligibility of isolated genes ${ }^{81}$ and also arguing the Federal Circuit misapplied Mayo to the facts of Association for Molecular Pathology. ${ }^{82}$

\section{a. Patent Eligibility of Myriad's Claims to Genes as Compositions of Matter}

The challenged patent claims outlined above include two types of claims: (1) a composition-of-matter claim to isolated DNA and (2) claims to diagnostic methods. Both types of claims generate controversy in the context of gene patents; accordingly, each type is analyzed separately below.

The U.S. Patent and Trademark Office (USPTO) has long held isolated DNA molecules to be patent-eligible subject matter, ${ }^{83}$ but the topic nonetheless has been the subject of much debate. Michael Crichton famously wrote, "You, or someone you love, may die because of a gene patent that should never have been granted in the first place." ${ }^{84}$ Crichton went on to describe genes existing in an individual's body as the "private property" of the patent holder. ${ }^{85}$ This statement mischaracterizes the science and the law at issue in gene patents, because, as explained in Part II.B.1, gene patents claim isolated genes, not genes as they exist in the

79. Ass’n for Molecular Pathology v. Myriad Genetics, Inc., 132 S. Ct. 1794, 1794 (2012) (mem.).

80. Ass’n for Molecular Pathology v. U.S. Patent \& Trademark Office, 689 F.3d 1303, 1325 (Fed. Cir. 2012), petition for cert. filed, Sept. 25, 2012.

81. Petition for a Writ of Certiorari at 21, Ass'n for Molecular Pathology, 689 F.3d 1303 (Fed. Cir. 2012) (No. 2010-1406), 2012 U.S. S. Ct. Briefs LEXIS 4098, at 35.

82. Id. at 31, 2012 U.S. S. Ct. Briefs LEXIS 4098, at 49.

83. See Utility Examination Guidelines, 66 Fed. Reg. 1092, 1093 (Jan. 5, 2001), www.uspto.gov/web/offices/com/sol/notices/utilexmguide.pdf (“[A]n inventor's discovery of a gene can be the basis for a patent on the genetic composition isolated from its natural state and processed through purifying steps that separate the gene from other molecules naturally associated with it."); see also Andrew W. Torrance, Gene Concepts, Gene Talk, and Gene Patents, 11 MinN. J. L. SCI. \& TECH. 157, 176-77 (2010) (describing a patent issued in 1982 that was the first to "claim[] genes per se").

84. Michael Crichton, Patenting Life, N.Y. Times, Feb. 13, 2007, http://www.nytimes.com/2007/02/13/opinion/13crichton.html.

85. Id. 
human body. Crichton's statement does, however, reflect some of the concerns triggered by patents relating to the human body. ${ }^{86}$

Nonetheless, in keeping with the USPTO's longstanding position on patent claims involving genes, the Federal Circuit in its original decision in Association for Molecular Pathology held that "claims to isolated DNAs . . a are directed to patent-eligible subject matter under $\S 101 ., 87$ In so doing, the Federal Circuit reversed the district court's attempt to fit isolated DNA molecules within the "products of nature" exception to patent eligibility. ${ }^{88}$ On remand from the Supreme Court, the Federal Circuit stated that Mayo does not control the question of patent eligibility with respect to the composition-of-matter claims, ${ }^{89}$ and therefore reaffirmed its earlier ruling upholding those claims. Using the framework provided by Diamond v. Chakrabarty ${ }^{90}$ and Funk Bros. Seed Co. v. Kalo Inoculant Co., ${ }^{91}$ the Federal Circuit asserted that "[o]ne distinction ... between products of nature and human-made invention for purposes of $\S 101$ turns on a change in the claimed composition's identity compared with what exists in nature."92

In Chakrabarty, the Court held that a manmade living organism was patent-eligible subject matter. $^{93}$ The bacteria at issue were genetically engineered to break down multiple components of crude oil, which no single naturally occurring bacterium could do. ${ }^{94}$ This capability had important applications in cleaning oil spills. ${ }^{95}$ Because the "claim [was] not to a hitherto unknown natural phenomenon, but to a nonnaturally

86. See, e.g., Ass'n for Molecular Pathology v. U.S. Patent \& Trademark Office, 653 F.3d 1329, 1354 (Fed. Cir. 2011) (discussing concerns that gene patents open the door to patenting a person's organs), vacated sub nom. Ass'n for Molecular Pathology v. Myriad Genetics, Inc., 132 S. Ct. 1794 (2012).

87. Id. at 1350 .

88. Ass'n for Molecular Pathology v. U.S. Patent \& Trademark Office, 702 F. Supp. 2d 181, 220-32 (S.D.N.Y. 2010), aff'd in part, rev'd in part, 653 F.3d 1329 (Fed. Cir. 2011), vacated sub nom. Ass'n for Molecular Pathology v. Myriad Genetics, Inc., 132 S. Ct. 1794 (2012).

89. As discussed in Part II.B.2.b.ii., infra, Mayo invalided method claims that preempted a law of nature. On remand, the Federal Circuit in Association for Molecular Pathology held that Mayo was inapplicable to the patent eligibility of isolated DNA, because "[a] composition of matter is not a law of nature.” Ass'n for Molecular Pathology v. U.S. Patent \& Trademark Office, 689 F.3d 1303, 1331 (Fed. Cir. 2012), petition for cert. filed, Sept. 25, 2012.

90. 447 U.S. 303 (1980).

91. 333 U.S. 127 (1948).

92. Ass'n for Molecular Pathology, 689 F.3d at 1327-28.

93. Chakrabarty, 447 U.S. at 310.

94. Id. at 305.

95. Id. at n.2. 
occurring manufacture or composition of matter-a product of human ingenuity 'having a distinctive name, character [and] use,'” the Court held the bacteria to be patent eligible. ${ }^{96}$ The Court distinguished the bacteria in Chakrabarty from the newly discovered but naturally occurring bacterial trait that was held to be patent-ineligible subject matter in Funk Bros., finding that the bacteria in Chakrabarty had "markedly different characteristics from any [bacterium] found in nature," derived from the efforts of the patentee. ${ }^{97}$

Relying on Chakrabarty, the Federal Circuit in Association for Molecular Pathology concluded that claims to isolated DNA molecules are "drawn to patent-eligible subject matter because the claims cover molecules that are markedly different-have a distinctive chemical structure and identity-from those found in nature." ${ }^{\text {" }}$ The court relied on the fact that isolated DNA molecules are cleaved from a larger structural complex or, in some cases, are chemically synthesized, giving them a chemical structure different from that of native DNA. ${ }^{99}$ A DNA molecule, "when it is bonded to other genetic material, is worlds apart from... an isolated DNA molecule that is in hand and usable."100 Patents encourage and protect inventive activities that "reduc[e] a portion of nature to concrete form." 101

The court rejected the plaintiffs' argument that isolated DNA is not "markedly different" from native DNA because they both share the same nucleotide sequence. ${ }^{102}$ The court reasoned that "the patent eligibility of an isolated DNA is not negated because it has similar informational properties to a different, more complex natural material." Instead the court relied on the distinct structure and identity of isolated DNA to uphold its patent eligibility. ${ }^{103}$ The court concluded that isolated DNA is a manmade invention, rather than a product of nature, and is therefore patent-eligible subject matter. ${ }^{104}$

96. Id. at 309-10 (second alteration in original) (quoting Hartranft v. Wiegmann, 121 U.S. 609, 615 (1887)).

97. Id. at 310 .

98. Ass'n for Molecular Pathology v. U.S. Patent \& Trademark Office, 689 F.3d 1303, 1328 (Fed. Cir. 2012), petition for cert. filed, Sept. 25, 2012.

99. Id. at 1328.

100. Id. at 1331.

101. Id.

102. Id. at 1330 (internal quotation marks omitted).

103. Id.

104. Id. 


\section{b. Patent Eligibility of Myriad's Claims to Diagnostic Methods}

Diagnostic method claims, like those at issue in Association for Molecular Pathology, have been a source of controversy in other recent cases. ${ }^{105}$ Diagnostic method claims are directed to a "correlation between a patient's medical data and a medical prognosis."106 For example, a claim directed to a method for measuring the level of a particular amino acid in a patient and using that measurement to diagnose a vitamin deficiency is a diagnostic method claim. ${ }^{107}$ Genetic diagnostic claims involve correlations between a specific DNA sequence and a particular disease. ${ }^{108}$ These types of claims raise concerns because a correlation is a law of nature ${ }^{109}$ - the fact that a certain measurement indicates a vitamin deficiency, or that a certain genetic mutation indicates an increased risk of disease is a naturally occurring correlation that cannot be patented. But, a method that applies that law of nature to a diagnostic purpose can be patented. ${ }^{110}$ Thus, concerns arise that a diagnostic method patent comes too close to patenting the law of nature itself, thereby allowing the patent holder to circumvent the established rules of patent eligibility.

105. See, e.g., Classen Immunotherapies, Inc. v. Biogen IDEC, 659 F.3d 1057, 1060-61 (Fed. Cir. 2011), petition for cert. filed, Feb. 28, 2012; Prometheus Labs. v. Mayo Collaborative Servs., 628 F.3d 1347, 1649-51 (Fed. Cir. 2010), rev'd, 132 S. Ct. 1289 (2012).

106. Asher Hodes, Note, Diagnosing Patentable Subject Matter, 26 BerKeley TeCH. L.J. 225, 225 (2011).

107. See Metabolite Labs. v. Lab. Corp. of Am. Holdings, 370 F.3d 1354, 1358-59 (Fed. Cir. 2004), cert. granted, 546 U.S. 975 (2005), and cert. dismissed, 548 U.S. 124 (2006) (per curiam). In Metabolite Laboratories, the patent at issue centered on a correlation between elevated levels of a particular amino acid and a B vitamin deficiency. Id. at 1358 . The patent eligibility of the diagnostic method claim was not challenged in the Federal Circuit, so the court did not address this issue. See id. at 1365-69 (describing Lab Corp.'s asserted grounds for patent invalidity). The Supreme Court initially granted certiorari, but then dismissed the writ as improvidently granted. Lab. Corp. of Am. Holdings v. Metabolite Labs., 548 U.S. 124, 125 (2006) (per curiam). Justice Breyer, joined by Justice Stevens and Justice Souter, dissented from the dismissal, arguing the Court should have ruled on the issue of patent eligibility and expressing the view that the claim is directed to a patent-ineligible phenomenon of nature. Id. at 138 (Breyer, J., dissenting).

108. Hodes, supra note 106, at 243-44, 247-48.

109. See Metabolite Labs., 548 U.S. at 135, 137-38 (Breyer, J., dissenting).

110. See Diamond v. Diehr, 450 U.S. 175, 187 (1981) (stating that "an application of a law of nature ... to a known ... process may well be deserving of patent protection" (citing Funk Bros. Seed Co. v. Kalo Inoculant Co., 333 U.S. 127 (1948); Eibel Process Co. v. Minn. \& Ont. Paper Co., 261 U.S. 45 (1923); Cochrane v. Deener, 94 U.S. 780 (1877); O’Reilly v. Morse, 56 U.S. 62 (1854); Le Roy v. Tatham, 55 U.S. 156 (1853))). 
However, diagnostic method claims must pass the threshold test pertaining to patent-eligible subject matter, ${ }^{111}$ which should theoretically avoid the realization of such concerns. Courts consider a variety of factors in determining the patent eligibility of a claimed method. The machine-or-transformation test is one such consideration. ${ }^{112}$ Under this test, courts determine whether the claim "(1) ... is tied to a particular machine or apparatus, or (2) ... transforms a particular article into a different state or thing." 113 The presence of these factors can support a finding of patent eligibility. ${ }^{114}$ Although the Court recently held that the machine-or-transformation test is not a bright-line rule and is not conclusive on the issue of patent eligibility, it also noted that the test is a "useful and important clue." 115 Thus, the test remains relevant to discussions regarding the patent eligibility of diagnostic method claims.

\section{i. The Federal Circuit's Original Decision}

In its original decision in Association for Molecular Pathology, the Federal Circuit addressed the patent eligibility of Myriad's "method claims directed to 'comparing' or 'analyzing' DNA sequences," finding those claims to fit into the "abstract, mental steps" exception to patenteligible subject matter. ${ }^{116}$ Myriad's "comparing” and "analyzing” claim language describes a "'method for screening a tumor sample,' by 'comparing' a first BRCA1 sequence from a tumor sample and a second BRCA1 sequence from a non-tumor sample, wherein a difference in sequence indicates an alteration in the tumor sample."117 The court held this claim describes only the abstract mental steps involved in comparing two strings of nucleotide bases, and it was therefore not directed to a patent-eligible process. ${ }^{118}$

\footnotetext{
111. Bilski v. Kappos, 130 S. Ct. 3218, 3225 (2010).

112. Id. at 3225-28.

113. In re Bilski, 545 F.3d 943, 954 (Fed. Cir. 2008), aff'd sub nom. Bilski v. Kappos, 130 S. Ct. 3218 (2010).

114. Bilski, 130 S. Ct. at 3227.

115. Id

116. Ass'n for Molecular Pathology v. U.S. Patent \& Trademark Office, 653 F.3d 1329, 1334 (Fed. Cir. 2011), vacated sub nom. Ass'n for Molecular Pathology v. Myriad Genetics, Inc., 132 S. Ct. 1794 (2012).

117. Id. at 1355-56 (quoting U.S. Patent No. 5,710,001 (filed June 7, 1995)).

118. Id. at 1357.
} 
Also in its original decision, the Federal Circuit held one of Myriad's method claims to be patent eligible. Myriad's claim to a "method for screening potential cancer therapeutics" included "steps of 'growing' transformed cells in the presence or absence of a potential cancer therapeutic, an inherently transformative step involving the manipulation of the cells and their growth medium," as well as "ddetermining' the cells' growth rates, a step that also necessarily involves physical manipulation of the cells." 119 The court found both of these steps to be central to the claimed diagnostic method and therefore held the claim to be directed to patent-eligible subject matter. ${ }^{120}$

\section{ii. Further Consideration in Light of Mayo Collaborative Services}

Following the Federal Circuit's decision in Association for Molecular Pathology, the Supreme Court granted certiorari, vacated the judgment, and remanded the case to the Federal Circuit for reconsideration in light of the Court's decision in Mayo Collaborative Services v. Prometheus Laboratories. ${ }^{121}$ The claims at issue in Mayo involved a method for optimizing the efficacy of a patient's autoimmune disease treatment. ${ }^{122}$ The method used natural laws to describe the relationship between a drug's metabolite levels in a patient and the efficacy or toxicity of drug treatment. ${ }^{123}$ Specifically, one patent claim set forth the following relationships: if the metabolite levels exceed a certain threshold, then the administered dose is likely to induce harmful side effects, so the dose should be decreased; conversely, if the metabolite levels are lower than a certain threshold, then the administered dose is likely ineffective, so the dose should be increased. ${ }^{124}$ The Federal Circuit in Mayo found that the claimed steps of administering a drug to a patient, determining the drug's metabolite levels in the patient, and using those metabolite measurements to determine subsequent drug dosages constituted the "application of naturally occurring correlations," and therefore held the method to be

\footnotetext{
119. Id.

120. Id.

121. Ass'n for Molecular Pathology v. Myriad Genetics, Inc., 132 S. Ct. 1794, 1794 (2012) (mem.), remanded to sub nom. Ass'n for Molecular Pathology v. U.S. Patent \& Trademark Office, 689 F.3d 1303 (Fed. Cir. 2012).

122. Mayo Collaborative Servs. v. Prometheus Labs., 132 S. Ct. 1289, 1294 (2012).

123. Id.

124. See id.
} 
directed to patent-eligible subject matter. ${ }^{125}$ The court also found that the method satisfied the machine-or-transformation test, as administering a drug transforms a patient's body chemistry, and determining metabolite levels requires transforming blood and tissue samples to extract metabolites and determine their levels. ${ }^{126}$ Finding these steps to be central to the claim ${ }^{127}$-as opposed to mere data-gathering steps, which are not patentable as processes under $\S 101^{128}$-the Federal Circuit held the diagnostic method claim in Mayo was directed to patent-eligible subject matter. ${ }^{129}$

The Supreme Court reversed, however, holding that the claims in Mayo attempted to patent a law of nature. ${ }^{130}$ The Court summarized the claims as instructing doctors to "(1) measure (somehow) the current level of the relevant metabolite, (2) use particular (unpatentable) laws of nature... to calculate the current toxicity/inefficacy limits, and (3) reconsider the drug dosage in light of the law." ${ }^{31}$ In other words, the Court found that the claim simply stated the law, and then told doctors to somehow apply it. ${ }^{132}$

Upon further consideration in light of Mayo, the Federal Circuit in Association for Molecular Pathology reaffirmed its earlier ruling with respect to Myriad's method claims. ${ }^{133}$ The court again invalidated the "comparing" and "analyzing" claims, reiterating its prior logic for finding the claims to cover an abstract mental process, and further finding the claims "indistinguishable" from the claims invalidated by the

125. Prometheus Labs. v. Mayo Collaborative Servs., 628 F.3d 1347, 1350-51, 1355 (Fed. Cir. 2010), rev'd, 132 S. Ct. 1289 (2012).

126. Id. at 1355-57.

127. Id. at 1357.

128. Id. The Federal Circuit distinguished the claims at issue in Prometheus Laboratories from prior cases involving claims that attempted to patent data-gathering steps. Id. One applicant claimed a process for "(1) performing a clinical test on individuals and (2) based on the data from that test, determining if an abnormality existed and determining the possible causes of any abnormality by using an algorithm.” Id. at 1358 (citing In re Grams, 888 F.2d 835, 839-41 (Fed. Cir. 1989)). The clinical tests were not transformative; they were performed only to gather data. Id. (citing Grams, 888 F.2d at 840). A mathematical algorithm in combination with gathering data is not patent eligible and thus the claimed methods were not patent eligible. Id. (quoting In re Bilski, 545 F.3d 943, 963 (2008)).

129. Id. at 1359.

130. Mayo Collaborative Servs. v. Prometheus Labs., 132 S. Ct. 1289, 1297 (2012).

131. Id. at 1299.

132. Id. at 1299-1300.

133. Ass'n for Molecular Pathology v. U.S. Patent \& Trademark Office, 689 F.3d 1303, 133334 (Fed. Cir. 2012), petition for cert. filed, Sept. 25, 2012. 
Supreme Court Mayo. ${ }^{134}$ Neither the claims at issue in Mayo, nor the "comparing" and "analyzing" claims in Association for Molecular Pathology, were "sufficiently transformative" of what otherwise constituted a natural law or abstract idea. ${ }^{135}$

In contrast, the Federal Circuit upheld Myriad's claim to a method for screening potential cancer therapeutics. ${ }^{136}$ In doing so, the court both affirmed its prior logic and distinguished the screening method from the claims at issue in Mayo. ${ }^{137}$ Myriad's method claim comprises “(1) growing host cells transformed with an altered BRCA1 gene in the presence or absence of a potential cancer therapeutic, (2) determining the growth rate of the host cells with or without the potential therapeutic, and (3) comparing the growth rate of the host cells."138 The plaintiffs argued that the "determining" and "comparing" steps preempted a law of nature, like the claims that were invalidated in Mayo. ${ }^{139}$ The court, however, focused on the "transformed" nature of the cells - in other words, the cells are not naturally occurring, but are instead "derived by altering a cell to include a foreign gene, resulting in a man-made, transformed cell with enhanced function and utility."140 Thus, the screening method is more than an abstract mental step or law of nature, and the claim does more than "simply state the law of nature while adding the words 'apply it.",141 Rather, the claim recites steps that are applied to manmade, transformed cells. $^{142}$ Because the underlying subject matter-a manmade, transformed cell—is patent eligible, a method applying various procedures to that subject is also patent eligible. ${ }^{143}$ This distinguishes Myriad's claim from the claims in Mayo, where the recited steps were insufficient to differentiate the method from the underlying law of nature. ${ }^{144}$ Therefore, the court reaffirmed its prior ruling and

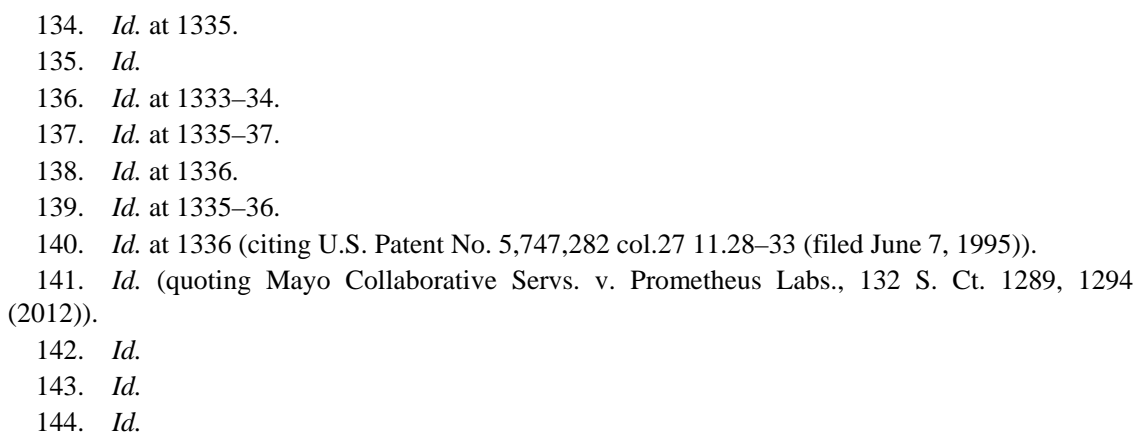


upheld the patent eligibility of the claim to a method for screening therapeutics. ${ }^{145}$

Now, the Supreme Court has second opportunity to weigh-in on the issue of patent-eligible subject matter, as the plaintiffs have filed a second petition for certiorari.

\section{Opposing Policy Concerns Give Rise to the Gene Patent Debate}

Proponents of gene patents argue that patents are needed to incentivize invention, commercialization of valuable inventions, and disclosure of information for the benefit of the public, and that these incentives are particularly important in the biotechnology industry. Opponents of gene patents fear that patented services and testing will be unaffordable or otherwise inaccessible to consumers. These opposing positions give rise to the gene patent debate; each position is discussed in greater detail below. The effect of gene patents on whole genome sequencing and personalized medicine is an especially important topic in the debate, so it receives its own section.

\section{Incentivizing Genetic Research}

Patents incentivize individuals to invest their time and money in discovering and commercializing inventions that ultimately benefit society. ${ }^{146}$ This is especially true in the biotechnology industry. In fact, patents for genes have been characterized as the "fuel" for the "R\&D engine" that produces and commercializes biotechnologies. ${ }^{147}$ For example, Myriad has spent over $\$ 500$ million developing and commercializing its BRCA tests. ${ }^{148}$ Richard Marsh, executive vice president, general counsel, and secretary of Myriad, has said that it took Myriad over ten years to recoup on its investment in BRCA tests and that

\footnotetext{
145. Id. at 1337.

146. See supra notes 5-17 and accompanying text.

147. Brief of Amici Curiae Christopher M. Holman \& Robert Cook-Deegan in Support of Neither Party at 7-8, Ass'n for Molecular Pathology v. U.S. Patent \& Trademark Office, 653 F.3d 1329 (Fed. Cir. 2011) (No. 2010-1406), 2010 WL 4853323, at *7-*8 (quoting OFFICE OF TECH. ASSESSMENT, OTA-BA-218, COMMERCIAL BIOTECHNOLOGY: AN INTERNATIONAL ANALYSIS (1984); OfFice of Tech. Assessment, OTA-BA-494, Biotechnology IN A GLOBAL ECONOMY (1991); FTC, EMERGING HEALTHCARE ISSUES: Follow-On BIOLOGIC DRUG COMPETITION (2009)).

148. See The Defendants: An Interview with Richard Marsh of Myriad Genetics, GENEWATCH, Oct.-Dec. 2010, at 13 [hereinafter The Defendants], available at http://issuu.com /genewatchmagazine/docs/genewatch23-5.
} 
the promise of patent protection was the only reason Myriad was able to make the initial research and development investment. ${ }^{149}$ Due to the significant time and money required to develop and commercialize biotechnologies, researchers and investors need assurance that intellectual property protection will enable them to realize some return on their investment. ${ }^{150}$

But, there is more to the story of the biotechnology industry's need for intellectual property rights. Myriad is a large corporation, with over 1,100 employees and fiscal year 2011 revenue of over $\$ 400$ million. $^{151}$ Most biotechnology companies, however, are small start-up businesses, with less than 50 employees working on products that may take over a decade to produce. ${ }^{152}$ Because these businesses generate no immediate revenue from product sales, they must raise hundreds of millions of dollars to research, develop, and commercialize their inventions. ${ }^{153}$ "Patents 'are typically the only assets those firms possess that are sufficiently stable and valuable to attract the large amounts of capital they need to exploit promising research toward new drugs and diagnostics." 154 Thus, patent rights are critical to the survival and success of these small biotechnology companies.

Nonetheless, some scholars oppose the assertion that patents are necessary to stimulate scientific innovation. The Secretary's Advisory Committee on Genetics, Health, and Society (SACGHS) investigated "the effects of patents and licensing practices on basic genetic research, genetic test development, patient access to genetic tests, and genetic testing quality," concluding that "patents on genetic discoveries do not

149. Id.

150. See, e.g., id. (quoting Richard Marsh as saying that Myriad would not invest time or money in a product unless they know there is some promise of intellectual property protection).

151. Investor Relations, MYRIAD, http://investor.myriad.com (last visited Aug. 23, 2012).

152. Brief for Biotechnology Industry Organization \& the Ass'n of University Technology Managers as Amici Curiae Supporting Reversal at 25, Ass'n for Molecular Pathology, 653 F.3d 1329 (No. 2010-1406), 2010 WL 4853322, at *25 (citing BIOTECHNOLOGY INDUS. ORG., GUIDE TO BioteChNOLOGY 2008, at 2, 77 (2008)); see also ERNST \& Young, BEYOND BordERs: GLOBAL BIOTECHNOLOGY REPORT 2011, at 2, 40 (2011), http://www.ey.com/Publication/vwLUAssets/ Beyond_borders_global_biotechnology_report_2011/\$FILE/Beyond_borders_global_biotechnology _report_2011.pdf (reporting biotechnology industry statistics for 2010 and showing that of the 315 publicly traded biotechnology companies, thirteen "commercial leaders" in the industry employ 74,230 individuals, while 38,000 employees are spread among the remaining 302 companies).

153. Brief for Biotechnology Industry Organization \& the Ass'n of University Technology Managers as Amici Curiae Supporting Reversal, supra note 152, at 25-26.

154. Id. at 26 (quoting Claude Barfield \& John E. CALfeE, Biotechnology and the PATENT System 27 (2007)). 
appear to be necessary for either basic genetic research or the development of available genetic tests."

SACGHS found that scientists are usually motivated to conduct research by a "desire to advance understanding, the hope of improving patient care through new discoveries, and concerns for their own career advancement," rather than by the promise of patent protection. ${ }^{156}$ Furthermore, SACGHS stated that much of the funding for basic genetic research likely comes from the federal government, ${ }^{157}$ so using patents to stimulate private investment is not essential to promoting basic genetic research. ${ }^{158}$ Academia already encourages sharing research and publishing discoveries, ${ }^{159}$ and in industry, the clinical community requires disclosure before accepting new healthcare products or services, so the report concluded that patents are not needed to stimulate disclosure. ${ }^{160}$

SACGHS also concluded that exclusive rights conferred by a patent do not necessarily spur faster test development. ${ }^{161}$ SACGHS studied a number of tests and did not find that patent protection corresponded to

155. Steven Teutsch, Introductory Letter to SEC'Y's AdVISORY COMM. ON GENETICS, HEALTH, \& SOC’Y, DEP'T OF HEALTH \& HUMAN SERVS., GENE PATENTS AND LiCENSING PRACTICES AND THEIR IMPACT ON PATIENT ACCESS TO GENETIC TESTS (2010), http://oba.od.nih.gov/ oba/sacghs/reports/sacghs_patents_report_2010.pdf. But see the Statement of Dissent to the SACGHS report, which recognizes the importance of supporting innovation and converting genetic discoveries into accessible diagnostic and treatment tools, and also notes that the cost of developing these tools has dramatically increased. Mara Aspinall et al., Statement of Dissent to SEC'Y'S Advisory Comm. on Genetics, Health, \& Soc’y, Dep’t of Health \& Human Servi., Gene Patents and Licensing Practices and Their Impact on Patient Access to Genetic Tests (2010), http://oba.od.nih.gov/oba/sacghs/reports/sacghs_patents_report_2010.pdf. The Statement of Dissent concludes that while the patent system might not be perfect, it gives researchers and investors some value in return for their time and money. Id.

156. SEC'Y'S ADVISORY COMM. ON GENETICS, HEALTH, \& SOC’Y, DEP’T OF HEALTH \& HUMAN SERvs., Gene Patents and Licensing Practices and Their Impact on Patient ACCess to GENETIC TESTS (2010), http://oba.od.nih.gov/oba/sacghs/reports/sacghs_Patents_report_2010.pdf [hereinafter SACGHS GENE PATENTS REPORT] (citing John M. Golden, Biotechnology, Technology Policy, and Patentability: Natural Products and Invention in the American System, 50 EMORY L.J. 101 (2001)).

157. Id. at 2 (citing NAT'L SCI. BD., NAT'L. SCI. FOUND., SCIENCE AND ENGINEERING INDICATORS 2008 (2008)).

158. Id

159. Id. (citing Robert K. Merton, THE SOCiology of SCIENCE: THEORETICAL AND EMPIRICAL INVESTIGATIONS (1973); Margo A. Bagley, Academic Discourse and Proprietary Rights: Putting Patents in Their Proper Place, 47 B.C. L. Rev. 217 (2006); Kira R. Fabrizio \& Alberto Di Minin, Commercializing the Laboratory: Faculty Patenting and the Open Science Environment, 37 RESEARCH POL'Y 914 (2008)).

160. Id.

161. Id. 
the speed with which a test reaches the market. ${ }^{162}$ The SACGHS report determined that not only are patents unneeded to motivate genetic research and investment in genetic research, but also that patents can actually harm these goals by discouraging follow-on research. ${ }^{163}$ In some cases, SACGHS found, patents are used to gain a market advantage over existing competition, which limits access and does not provide the benefit of stimulating innovation. ${ }^{164}$

\section{Availability and Affordability of Medical Testing}

Patient access to genetic testing depends on "first, basic genetic research that generates insights into the genetic basis of particular diseases and, second, efforts to translate those discoveries into clinically useful, widely available tests." ${ }^{65}$ The SACGHS report theorized that when a single entity holds a patent to a genetic test, patients have limited access to high-quality testing for a number of reasons. ${ }^{166}$ If the sole provider of the test does not accept the patient's insurance, the patient might be unable to afford the test. ${ }^{167}$ Additionally, second-opinion testing is unavailable. ${ }^{168}$ Finally, the SACGHS report expresses concerns about patents eliminating competition that would otherwise lead to improved quality of testing techniques, and thus limiting patient access to high-quality testing. ${ }^{169}$

However, three of the eighteen voting members of SACGHS issued a dissenting statement to the SACGHS report. ${ }^{170}$ The dissent challenged the conclusions of the SACGHS report, noting that in general, the current U.S. healthcare system does not provide equal, unlimited access to medical care and diagnostic tests. ${ }^{171}$ Patient access to healthcare is not a problem unique to genetic testing and therefore will not be solved by

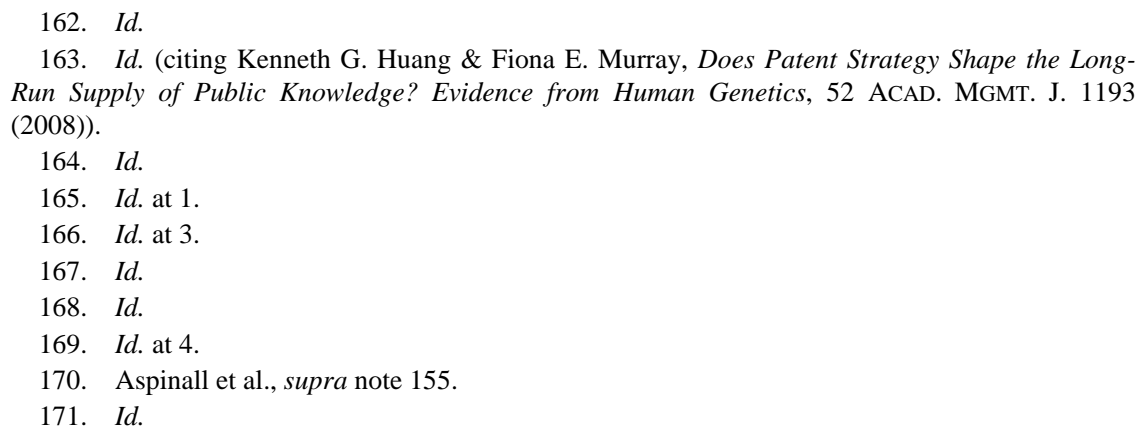


patent law reform. ${ }^{172}$ Insurance companies are free to refuse to cover genetic testing, regardless of related patents or the number of providers offering the tests. ${ }^{173}$ The dissent stated that implementing the SACGHS report recommendations would do more harm than good in terms of patient access to high-quality genetic testing. ${ }^{174}$

Additionally, when SACGHS commissioned case studies to determine the effect of patents and exclusive licenses on the price of genetic tests, the case studies did not produce evidence that patents and exclusive licenses consistently lead to higher costs to patients. ${ }^{175}$ While SACGHS investigated claims that patents lead to inflated prices for genetic tests, it found no concrete evidence to this effect. ${ }^{176}$ In fact, one case study found that the unit price of the full-sequence BRCA test was comparable to other full-sequence tests performed at both commercial and nonprofit laboratories. ${ }^{177}$

3. The Patent Thicket and Its Implications for Whole Genome

Sequencing and Personalized Medicine

In addition to general availability and affordability concerns, gene patent opponents specifically voice a major concern about the effect gene patents will have on whole-genome sequencing and personalized medicine. ${ }^{178}$ Opponents fear that as an increasing number of gene patents are issued to many different inventors, these intellectual property rights will create a "patent thicket," forcing a whole-genome sequencing firm to negotiate licenses with each holder of a gene patent, potentially requiring thousands of licenses from many licensors. ${ }^{179}$ The cost of determining the scope and validity of each patent and negotiating

\footnotetext{
172. See id.

173. Id.

174. Id.

175. SACGHS GENE PATENTS REPORT, supra note 156, at 38-39.

176. Id. at 39 .

177. Id. at 38; Robert Cook-Deegan et al., Impact of Gene Patents and Licensing Practices on Access to Genetic Testing for Inherited Susceptibility to Cancer: Comparing Breast and Ovarian Cancers with Colon Cancers, 12 GENETICS MED. S15, S20-24 (2010), reprinted in SACGHS GENE PATENTS REPORT, supra note 156, A-11 to -18 app.A.

178. See, e.g., Ass'n for Molecular Pathology v. U.S. Patent \& Trademark Office, 653 F.3d 1329, 1373, 1379-80 (Fed. Cir. 2011) (Bryson, J., concurring in part and dissenting in part) (fearing that the majority's decision to hold that claims to genes and gene fragments are patent eligible "will likely have broad consequences, such as preempting methods for whole-genome sequencing"), vacated sub nom. Ass'n for Molecular Pathology v. Myriad Genetics, Inc., 132 S. Ct. 1794 (2012).

179. See, e.g., id. at 1380 (citing SACGHS GENE PATENTS REPORT, supra note 156, at 50-51).
} 
licenses as necessary might prove to be prohibitively expensive and therefore might impede scientific progress in the fields of whole-genome sequencing and personalized medicine. ${ }^{180}$ The dissent in Association for Molecular Pathology worried that "this may well be [an area] in which 'too much patent protection can impede rather than promote the Progress of Science and useful Arts.", 181

However, whether this is a serious concern has yet to be determined; ${ }^{182}$ in fact, recent research reveals that current gene patents are unlikely to impede whole genome sequencing efforts in this way. First, there is a common misconception about the number of human genes that have actually been patented. ${ }^{183}$ There is a widely cited statistic that $20 \%$ of human genes are patented. ${ }^{184}$ But in fact, the study that led to this statistic actually demonstrated that "with respect to $20 \%$ of human genes known at the time they conducted their study, either (1) the DNA sequence of the gene, or (2) the amino acid sequence encoded by the gene, was mentioned in a US patent claim."185 Contrary to the interpretation many have given to the article describing the study's findings, the mere fact that a patent claim mentions a human gene does not altogether exclude others from using the gene. ${ }^{186}$ Thus, the quantity of existing gene patents does not necessarily create the feared patent thicket.

Furthermore, neither composition-of-matter claims to isolated genes nor diagnostic method claims involving genes are likely to impede progress in whole genome sequencing technology. Composition-of-

180. Id. (citing SACGHS Gene PATENTS RePORT, supra note 156, at 50-51; Rebecca S. Eisenberg, Noncompliance, Nonenforcement, Nonproblem? Rethinking the Anticommons in Biomedical Research, 45 Hous. L. REV. 1059, 1076-80 (2008)).

181. Id. (quoting Lab. Corp. of Am. Holdings v. Metabolite Labs., 548 U.S. 124, 126 (2006) (Breyer, J., dissenting)) (internal quotation marks omitted).

182. See W. Nicholson Price II, Unblocked Future: Why Gene Patents Won't Hinder Whole Genome Sequencing and Personalized Medicine, 33 CARDOZO L. REv. 1601, 1605 \& n.18 (2012) (explaining that Myriad's attorney in Association for Molecular Pathology stated in oral arguments that whole genome sequencing was unlikely to violate Myriad's patents).

183. Chris Holman, Will Gene Patents Impede Whole Genome Sequencing?: Deconstructing the Myth that 20\% of the Human Genome is Patented, HolmAN's BioteCH IP BLOG (Aug. 8, 2011, 6:12 PM), http://holmansbiotechipblog.blogspot.com/2011/08/will-gene-patents-impede-whole-genome. html.

184. Id. (explaining that while many sources cite this statistic, the idea is ultimately traceable back to a single article: Kyle Jensen \& Fiona Murray, Intellectual Property Landscape of the Human Genome, 310 SCIENCE 239 (2005)).

185. Id. (emphasis added).

186. See id. ("The implicit assumption that the 'gene patents' identified ... cover all uses of the gene ... mentioned in patent claims is clearly false.”). 
matter claims are unlikely to impede progress because current sequencing technology is unlikely to infringe a claim to an isolated DNA molecule. ${ }^{187}$

Infringement of a claim to the isolated gene itself occurs only if the specific DNA sequence claimed is created or used during whole genome sequencing. ${ }^{188}$ But current whole genome sequencing techniques are unlikely to do this; ${ }^{189}$ instead, current sequencing techniques break DNA into small fragments, typically ranging from twenty-five to 1,000 nucleotides in length, and then sequence those fragments one base at a time. ${ }^{190}$ Finally, the sequences for all fragments are assembled. ${ }^{191}$ Thus, the likelihood of whole genome sequencing infringing a patent claim to a specific gene depends on the size of fragments generated. ${ }^{192}$ A patent for a gene that is smaller than the fragments generated might be infringed by whole genome sequencing techniques. ${ }^{193}$ While there are genes with sequences less than 1,000 nucleotides long, they are few, so current whole genome sequencing methods are unlikely to infringe claims to isolated genes. $^{194}$

Method claims for comparing and analyzing sequences for diagnostic purposes are more likely to be infringed by whole genome sequencing, but are also unlikely to impede whole genome sequencing efforts for primarily two reasons. First, claims directed only to comparison methods are probably invalid as directed to patent-ineligible subject matter. ${ }^{195}$ Like the comparing and analyzing steps at issue in Association for Molecular Pathology, these claims to comparison methods attempt to patent abstract ideas or mental processes and are therefore not the type of discovery the patent laws are intended to protect. $^{196}$ Second, claims directed to patent-eligible processes involving genes are more likely to be valid, but infringement might be avoided by

\footnotetext{
187. Price, supra note 182, at 1622.

188. See id. at 1621.

189. Id. at 1622.

190. Id. at 1619-20 (citing Pauline C. Ng \& Ewen F. Kirkness, Whole Genome Sequencing, 628 Methods Molecular Biology 215, 216-17 (2010)).

191. Id. at 1620 (citing Ng \& Kirkness, supra note 190, at 216).

192. Id. at 1622 .

193. Id.

194. Id.

195. See, e.g., id. at 1627 (discussing the Federal Circuit's 2011 decision in Association for Molecular Pathology).

196. See supra notes $116-18$ and accompanying text.
} 
utilizing multiple actors to perform the steps in the method claim. ${ }^{197} \mathrm{~A}$ method claim is infringed only if a single actor performs all steps, or controls the performance of all steps, in the claim. ${ }^{198}$ If a genome sequencing company provides a patient with the results of his genetic sequencing, the company has performed only the initial step of the method claim. ${ }^{199}$ If the patient then takes his sequence to a physician who compares the patient's sequence to a database containing sequences for genetic mutations, the physician has performed only the comparing and analyzing step. ${ }^{200}$ While this is a somewhat simplified explanation of joint infringement, parties might avoid liability by having different actors perform these various steps. ${ }^{201}$

\section{ANALYSIS}

\section{A. Genes and Genetic Diagnostic Methods Should Not Be Categorically Excluded From Patent-Eligible Subject Matter}

Based on the current standards for patentability, isolated genes are eligible subject matter for patents. "[A]nything under the sun that is made by man" ${ }^{202}$ is an appropriate subject for a patent, and isolated DNA does not fit within one of the well-established exceptions to this general rule. $^{203}$ The Supreme Court has declined to carve out additional exceptions and has cautioned lower courts against doing so, suggesting that additional policy-based exceptions should come from Congress. ${ }^{204}$ But both the Court and Congress should be wary of "adopting categorical rules that might have wide-ranging and unforeseen impacts."205 The broad construction of the patent laws and the Court's hesitancy to recognize additional categorical exceptions to patent-eligible subject matter have been vital to affording patent protection to technological

\footnotetext{
197. Price, supra note 182, at 1628-29.

198. Id. at 1628 \& n.129 (citing Muniauction, Inc. v. Thompson Corp., 532 F.3d 1318, 1328-30 (Fed. Cir. 2008); BMC Res., Inc. v. Paymentech, L.P., 498 F.3d 1373, 1378-79 (Fed. Cir. 2007)). 
advances unimaginable at the time $\S 101$ was enacted. ${ }^{206}$ Thus, neither Congress nor the Court, if it again grants certiorari in Association for Molecular Pathology, should categorically exclude genes from patenteligible subject matter.

1. Utility, Novelty, Nonobviousness, and Disclosure Requirements Should Be Used to Invalidate Questionable Patent Claims

A party may challenge the validity of a particular patent claim by showing that the claim fails to meet the requirements of patentability. ${ }^{207}$ First, a party may argue that the claim is directed to patent-ineligible subject matter, i.e., the subject of the claim is not the type of discovery that should receive patent protection. ${ }^{208}$ As discussed above, the subject of a claim is patent ineligible if it is properly characterized as a law of nature, physical phenomenon, or abstract idea. ${ }^{209}$ Alternatively or additionally, a party can challenge the validity of a patent claim by showing that the discovery is not useful, new, or nonobvious, or that the claim does not satisfy statutory disclosure requirements. ${ }^{210}$ Even if the subject of a claim is patent eligible, failure to comply with any of the other statutory requirements for patentability will render the claim invalid. It is necessary to distinguish patent eligibility from the other requirements of patentability. Indeed, the Federal Circuit in Association for Molecular Pathology repeatedly distinguished the concept of patent eligibility from patentability, emphasizing that the case addressed only the former issue. ${ }^{211}$ A valid patent claim must be directed to patenteligible subject matter and satisfy the other criteria for patentability. A party can successfully challenge the validity of a patent claim without ever mentioning the patent eligibility of the subject matter. ${ }^{212}$

The requirements of utility, novelty, and nonobviousness should be used to invalidate questionable patent claims; a new categorical

\footnotetext{
206. J.E.M. Ag Supply, Inc. v. Pioneer Hi-Bred Int’l, Inc., 534 U.S. 124, 135 (2001).

207. See 6 CHIsum, supra note 5, § 19.01, at 19-6 (2007) (describing the patent invalidity defense to a claim of infringement).

208. 35 U.S.C. $\S 101(2006)$

209. See supra Part II.A.2.b.

210. 35 U.S.C. §§ 102-103, 112

211. Ass'n for Molecular Pathology v. U.S. Patent \& Trademark Office, 689 F.3d 1303, 1324, 1332, 1333 (Fed. Cir. 2012), petition for cert. filed, Sept. 25, 2012.

212. See, e.g., Graham v. John Deere Co., 383 U.S. 1, 37 (1966) (finding a patent claim invalid due to failure to meet the requirements of $\S 103$ ).
} 
exception to patent-eligible subject matter should not be used to achieve this purpose. By maintaining a broad interpretation of the statutory subject matter encompassed by $\S 101$ and relying on the other requirements of patentability to invalidate claims, courts can apply a fine filter to all claims and determine which warrant patent protection under the current laws.

The creation of a new categorical exception to patent-eligible subject matter, on the other hand, would not allow courts to finely filter patent claims relating to isolated DNA, but would instead simply toss out any patents relating to genes. To fully understand the undesirable consequences of this approach, it is necessary to consider the big picture as it pertains to gene patents. Much of the debate concerning gene patents focuses on the BRCA genes, Myriad's patents on those genes, and the consequences these patents have for breast cancer patients. This is only one aspect, though an important one, of the gene patent debate.

\section{Categorical Exclusion of Gene Patents Will Have Wide-Ranging and Unforeseen Impacts}

Because the USPTO has issued gene patents for decades, a categorical exclusion of gene patents threatens the settled property rights and expectations of the biotechnology industry. ${ }^{213}$ Furthermore, from a big-picture perspective, many biotechnology companies that have no interest in breast cancer research would suffer tremendously if genes were excluded from patent-eligible subject matter. All gene patent holders should not suffer from a challenge to merely fifteen patent claims within seven patents held by a single company. ${ }^{214}$ Hans Sauer, the Deputy General Counsel for Intellectual Property for the Biotechnology Industry Organization (BIO), ${ }^{215}$ posed an illustrative hypothetical. ${ }^{216}$ Suppose a small biotechnology firm after spending significant time and

213. Oral Argument at 33:57, Ass'n for Molecular Pathology, 689 F.3d 1303 (No. 2010-1406), available at http://www.cafc.uscourts.gov/oral-argument-recordings/2010-1406/2012-07-20/all.

214. See Ass'n for Molecular Pathology, 689 F.3d at 1309-10 (discussing the claims at issue).

215. BIO "provide[s] advocacy, business development, and communication services for over 1,100 [biotechnology companies] worldwide.” About BIO, BIO, http://www.bio.org/articles/aboutbio (last visited Aug. 24, 2012). BIO represents firms of all sizes involved in the research and development of "healthcare, agricultural, industrial, and environmental biotechnology products." Id.

216. Hans Sauer, Deputy Gen. Counsel for Intellectual Prop., Biotechnology Indus. Org., Remarks at Gene Patent Debate hosted by University of Missouri-Kansas City School of Law and The Joseph Cohen Lecture Fund: Do Gene Patents Kill? (Oct. 13, 2011). 
money on research and development ${ }^{217}$ obtains a patent on a cucumber gene. The company relies on this patent to recoup on its research investment. $^{218}$ A patent on a cucumber gene does not elicit the same emotional response that the BRCA genes do, but the cucumber gene patent holder's interests depend on the ultimate resolution of Association for Molecular Pathology. If genes are excluded from patent-eligible subject matter, the cucumber gene patent holder, along with all the other small biotechnology companies holding such patents, loses its intellectual property rights, its opportunity to profit from its research and development investments, and, ultimately, its ability to stay in business. ${ }^{219}$ While it is easy to lose sight of the cucumber patent holder among discussions about BRCA genes and Myriad, it is important to remember that the cucumber patent holder will fall as collateral damage to any action that narrows the scope of patent-eligible subject matter. Furthermore, as Part II.C.1 explains, most biotechnology firms are small businesses. The cucumber patent holder is actually the industry norm. These small businesses should not suffer from a categorical exclusion driven largely by a single, highly emotional case. Sauer's hypothetical illustrates the "wide-ranging and unforeseen impacts" that the Court in Bilski cautioned would follow from the adoption of a new categorical exclusion to patent-eligible subject matter. ${ }^{220}$

\section{B. Balancing the Competing Interests Surrounding Gene Patents}

While isolated genes are appropriate subject matter for patents, ${ }^{221}$ gene patents raise valid concerns about patient access to high-quality genetic tests. ${ }^{222}$ Congress should balance the interest of incentivizing scientific innovation with the availability of certain medical tests and treatments. In discussing potential methods for balancing these interests, two preliminary points are noteworthy. First, these competing interests are not unique to gene patents. As noted by the Federal Circuit, "Inherent in our patent system is a 'tension between the desire to freely

\footnotetext{
217. See supra Part II.C.1.

218. See supra Part II.C.1.

219. See supra Part II.C.1 (describing patents as typically the only assets sufficiently stable and valuable to secure the capital required for small biotechnology companies to develop and commercialize their inventions).

220. Bilski v. Kappos, 130 S. Ct. 3218, 3229 (2010).

221. See supra Part II.B.2.a.

222. See supra Part II.C.2.
} 
exploit the full potential of our inventive resources and the need to create an incentive to deploy those resources' by granting the right to exclude to those who promote the progress of the useful arts." ${ }^{223}$ The current system recognizes these competing interests, and the patentability requirements discussed above are the means chosen to balance them. Second, it is necessary to define the proper role of patent law in this debate. For example, some critics of gene patents complain that not all insurance companies cover genetic testing. ${ }^{224}$ Health insurance is undoubtedly an issue of great importance. But it is not a concern unique to genetic testing, nor is it the job of the USPTO to address such concerns. Neither the country's health insurance industry, nor a particular company's business practice is an issue properly addressed by the patent laws. Similarly, some critics of gene patents oppose the fees associated with genetic testing. ${ }^{225}$ Such criticism fails to account for the tremendous amount of time and money a company invests in developing such tests. While performing the actual test might be relatively inexpensive, the company likely spent hundreds of millions of dollars on researching and developing the test, which it must recoup. ${ }^{226}$ Again, these concerns fall outside the scope of issues properly addressed by patent law. Thus, the potential balancing solutions suggested below will not address such issues.

223. Cover v. Hydramatic Packing Co., 83 F.3d 1390, 1392 (Fed. Cir. 1996) (quoting Bonito Boats, Inc. v. Thunder Craft Boats, Inc., 489 U.S. 141, 152 (1989)).

224. See, e.g., Karen P. Mann, Gene Patents: Perspectives from the Clinical Laboratory, 14 MOLECULAR DiAGNOSIS \& THERAPY 137, 139 (2010) (describing a situation where a patient was forced to pay $\$ 10,000$ for a genetic test not covered by insurance). Myriad, however, has invested in educating the medical community and insurance industry, and provides free testing to individuals who exhibit a specified level of economic need. The Defendants, supra note 147, at 13-14.

225. See Andrew S. Robertson, The Role of DNA Patents in Genetic Test Innovation and Access, 9 NW. J. TeCH. \& INTELL. PRop. 377, 387 (2011) (noting that BRCA testing in the U.S. is five times as expensive as similar testing in areas where BRCA gene patents have been found invalid (citing Cook-Deegan et al., supra note 177, at 528)).

226.

[T] he Patent Act creates an incentive for innovation. The economic rewards during the period of exclusivity are the carrot. The patent owner expends resources in expectation of receiving this reward. Upon grant of the patent, the only limitation on the size of the carrot should be the dictates of the marketplace.

Biotechnology Indus. Org. v. District of Columbia, 496 F.3d 1362, 1372-73 (Fed. Cir. 2007) (alteration in original) (quoting King Instruments Corp. v. Perego, 65 F.3d 941, 950 (Fed. Cir. 1995)). 
[Vol. 61

\section{Suggestions from Previous Policy Reports}

Previous policy reports from around the world have suggested means for balancing these competing interests. ${ }^{227}$ The Nuffield Council on Bioethics suggested that the scope of protection for patents claiming isolated sequences of DNA be limited to the specific uses the inventor has demonstrated that the sequences may be put to, rendering the "scope of the monopoly awarded ... commensurate with the actual contribution by the inventor." 228 The Australian Law Reform Commission outlined an "experimental use exemption that would not be precluded by a commercial objective in undertaking the research."229 The Organisation for Economic Co-operation and Development ${ }^{230}$ encouraged patent holders to license genetic inventions "on terms and conditions that seek to ensure the widest public access to, and variety of, products and services based on the inventions." ${ }^{231}$ Finally, the Federal Trade Commission suggested that patents with an extremely broad scope should be limited, and that challenging invalid patents should be made easier. $^{232}$

The following discussion expands on some of these suggestions and examines their merits. Congress should enact a statutory research exemption for research activities involving patented genes and consider solutions like compulsory licensing or exercising march-in rights under the Bayh-Dole $\mathrm{Act}^{233}$ with caution, because such action seriously interferes with patentees' freedom to negotiate and enter into contracts. Most importantly, courts should interpret current patent law to properly construe the scope of claims to genes and genetic diagnostic methods and use the requirements for patentability to ensure that only deserving claims receive patent protection.

227. See SACGHS GENE PATENTS RePORT, supra note 155, at 81-83.

228. Id. at 81 (quoting NufField Council On Bioethics, The ETHiCs of PATENTING DNA 6566 (2002)) (internal quotation marks omitted).

229. Id. at 82 (citing AUSTL. LAW REFORM COMM'N, GENES AND INGENUITY: GENE PATENTING AND HUMAN HEALTH 24 (2004)).

230. The Organisation for Economic Co-operation and Development is a collaborative effort among 30 countries to address various challenges of globalization. Id.

231. Id. (quoting ORG. FOR ECON. CO-OPERATION AND DEV., GUIDELINES FOR THE LICENSING OF GENETIC INVENTIONS 9 (2006)) (internal quotation marks omitted).

232. Id. (citing FTC, To Promote InNovation: The Proper Balance of Competition and PATENT LAW AND POLICY 7-12 (2003), http://www.ftc.gov/os/2003/10/innovationrpt.pdf).

233. 35 U.S.C. $\S \S 200-212$ (2006). 


\section{Congress Should Enact a Statutory Research Exemption}

Congress should expand the current experimental use exemption to immunize researchers from infringement liability for their research efforts involving patented genes. The experimental use exemption is a product of common law that provides a defense to patent infringement for "experimental use."234 Many academic researchers assume their research activities are covered by the experimental use exemption, ${ }^{235}$ but the current exemption is actually quite narrow and covers a very limited class of research.

In Madey v. Duke University, the Federal Circuit established the narrow limits of the current doctrine. ${ }^{236}$ Prior to this case, there was little precedent to guide the application of the experimental use defense. ${ }^{237}$ In particular, there had been almost no cases in which a nonprofit, educational institution was alleged as the infringer. ${ }^{238}$ But this scenario arose in Madey, and the Federal Circuit rejected the fairly broad construction given to the experimental use exemption by the district court. $^{239}$ The district court classified experimental uses as those that are "solely for research, academic, or experimental purposes." 240 The district court, relying on a previous opinion from the Federal Circuit, further held that the exemption applied to experimental, nonprofit purposes. ${ }^{241}$ But, the Federal Circuit rejected this interpretation of the experimental use exemption and instead provided a much stricter construction. ${ }^{242}$ The court held that the exemption does not cover activities that are "in any way commercial in nature" or "conduct that ... keep[s] with the alleged infringer's legitimate business, regardless of commercial

234. Madey v. Duke Univ., 307 F.3d 1351, 1355 (Fed. Cir. 2002).

235. See Christopher M. Holman, The Impact of Human Gene Patents on Innovation and Access: A Survey of Human Gene Patent Litigation, 76 UMKC L. REV. 295, 305 (2007) (stating that many researchers “do not let the existence of patents dictate research agendas”).

236. Madey, 307 F.3d 1351.

237. Id. at 1362 .

238. Id.

239. Id. at 1361-62.

240. Id. at 1361 (quoting Madey v. Duke Univ., 266 F. Supp. 2d 420, 425 (M.D.N.C. 2001)) (internal quotation marks omitted).

241. Id. (quoting Madey, 266 F. Supp. 2d at 425). The district court relied on multiple cases, including Embrex, Inc. v. Service Engineering Corp., 216 F.3d 1343, 1349 (Fed. Cir. 2000), in reaching this conclusion. Madey, 266 F. Supp. 2d at 425.

242. Madey, 307 F.3d at 1362 (quoting Embrex, 216 F.3d at 1349). 
implications.”243 As applied to major research universities, school funded research projects further the university's "business objectives" by educating students and faculty, strengthening the school's reputation as a research institution, and attracting desirable students and faculty. ${ }^{244}$ Thus, the experimental use exemption does not afford immunity from infringement liability to such research. ${ }^{245}$ The Federal Circuit has made clear that the exemption applies only to activities undertaken for "amusement, to satisfy idle curiosity, or for strictly philosophical inquiry." 246

In reality, lawsuits against researchers are rare. ${ }^{247}$ A patent holder stands to gain little in either money or reputation by suing a research institution. ${ }^{248}$ Rather, lawsuits are more likely to arise when the alleged infringer is engaging in commercial activity. ${ }^{249}$ For example, Myriad only actively enforced its patents against researchers when they began performing commercial-level testing. ${ }^{250}$ Despite this reality, the mere possibility of being sued is likely enough to prevent some researchers from engaging in even noncommercial research activities. For this reason, a statutory research exemption would prove valuable.

Because the current experimental use exemption is so narrow, the Court must either broaden the construction of the current doctrine, or Congress must provide some type of statutory protection for research involving patented genes. Such congressional action would both encourage research and alleviate fear of lawsuits for patent infringement, thereby addressing several of the concerns of gene patent opponents. Enabling research on patented genes would allow nonholders of patents to confirm experimental results, enhance the quality of existing genetic tests, and promote further innovation involving the patented genes.

\footnotetext{
243. Id.

244. Id.

245. Id.

246. Id

247. See Christopher M. Holman, Learning From Litigation: What Can Lawsuits Teach Us About the Role of Human Gene Patents in Research and Innovation?, 18 KAN. J.L. \& PUB. POL'Y 215, 260-63 (2009).

248. See id. at 259 (distinguishing public, noncommercial research from private research, and noting that university research especially is perceived as being "more noble and in need of protection" than research by biotechnology companies, which are "portrayed as villains, using patents to block university research").

249. Id. at 260 .

250. The Defendants, supra note 148 , at $12-13$.
} 
3. Compulsory License Schemes Would Interfere with Patent Holders' Freedom to Contract and Are Not Desirable

A compulsory licensing scheme should not be implemented, because compulsory licenses will interfere with a patent holder's freedom to contract. Under a compulsory licensing scheme, the holder of a gene patent would be required to license certain patent rights to licensees. ${ }^{251}$ Some commentators have suggested that gene patent holders should be forced to license their rights to isolated sequences of DNA to any scientist conducting commercial research pertaining to the gene. ${ }^{252}$ In return, the licensee would pay a reasonable licensing fee to the licensor, with the fee based on the value of the product resulting from the licensee's research. ${ }^{253}$ In theory, this scheme encourages licensees to invest in research because the royalty they pay would be proportional to the success they achieve in their research. ${ }^{254}$ It also motivates patent holders to license their inventions because they would be compensated by successful licensees. ${ }^{255}$

Congress should not yet take such extreme action for multiple reasons. First, biotechnology companies already have natural incentives to engage in voluntary license agreements because each additional application involving the claimed gene increases the value of the patent. $^{256}$ Second, the right to exclude others from making, using, or selling a patented invention lies at the heart of patent rights, and a patentee has the right to refuse to license his patented product. ${ }^{257}$ The government should not interfere with a company's ability to freely enter into contractual license agreements with whomever the company chooses. And finally, there already exist some limits on a patentee's

251. See Donna M. Gitter, International Conflicts over Patenting Human DNA Sequences in the United States and the European Union: An Argument for Compulsory Licensing and a Fair-Use Exemption, 76 N.Y.U. L. REV. 1623, 1679 (2001) (describing a proposed compulsory licensing system).

252. See, e.g., id.

253. Id.

254. Id

255. Id

256. Id. at 1680 (citing Andrew Pollack, Is Everything for Sale?, N.Y. TIMES, June 28, 2000, at C1).

257. Cont’l Paper Bag Co. v. E. Paper Bag Co., 210 U.S. 405, 429 (1908) (“[E]xclusion may be said to [be] the very essence of the right conferred by the patent, as it is the privilege of any owner of property to use or not use it, without question of motive.” (citing Connolly v. Union Sewer Pipe Co., 184 U.S. 540, $546(1901)))$. 
right to exclude. One such limitation, an antitrust violation, arises if a patent holder: (1) sues to enforce a patent that "was obtained through knowing and willful fraud;",258 (2) brings a baseless infringement suit with the intent to inflict collateral, anticompetitive injury; ${ }^{259}$ or (3) illegally ties the sale of patented inventions to unpatented inventions, thereby gaining a monopoly beyond the scope of the patent. ${ }^{260}$ Thus, if a company exhibits particularly egregious behavior in regard to one of its patents, antitrust law might provide an appropriate remedy. Because there already exist remedies for extreme instances of a company refusing to deal with potential licensees, a compulsory license scheme is inappropriate until it is clear that anticompetitive licensing practices are a real problem with respect to gene patents.

\section{The Bayh-Dole Act Provides March-in Rights on Federally Funded}

Research, Which Should Be Exercised with Care

The Bayh-Dole Act places some limitations on patent rights to federally funded inventions. ${ }^{261}$ The Act enables recipients of federal funds to retain title to inventions developed with those funds. ${ }^{262}$ The purpose of the Act is to incentivize commercialization of federally funded inventions, because prior to the Act, when the government retained title to all federally funded inventions, the technology was rarely commercialized. $^{263}$ If the recipient of federal funding does choose to retain title, the funding agency has "march-in rights" on the patent. ${ }^{264}$ March-in rights enable the agency, under certain circumstances, to mandate that the recipient of federal funds grant a license for the patented invention to a third party. ${ }^{265}$ If the recipient fails to achieve a practical application for the patented invention, the agency has authority

\footnotetext{
258. In re Indep. Serv. Orgs. Antitrust Litig., 203 F.3d 1322, 1326 (Fed. Cir. 2000) (citing Glass Equip. Dev., Inc. v. Besten, Inc., 174 F.3d 1337, 1343 (Fed. Cir. 1999)).

259. See id. (citing Glass Equip., 174 F.3d at 1343).

260. Id. at 1327 (citing Atari Games Corp. v. Nintendo of Am., Inc., 897 F.2d 1572, 1576 (Fed. Cir. 1990)).

261. See 35 U.S.C. § 203 (2006).

262. Barbara M. McGarey \& Annette C. Levey, Patents, Products, and Public Health: An Analysis of the CellPro March-In Petition, 14 BERKELEY TECH. L.J. 1095, 1098 (1999).

263. Id. at 1097-98.

264. Id. at 1099.

265. 35 U.S.C. § 203(a).
} 
to exercise its march-in rights. ${ }^{266}$ March-in rights are also available if action is necessary to address health or safety needs. ${ }^{267}$

While no federal agency has actually exercised march-in rights yet, march-in petitions have requested that federal agencies march in and mandate licensing. For example, in 1997, CellPro sought a license for stem-cell separation technology that was developed at The Johns Hopkins University under a grant from the National Institutes of Health $(\mathrm{NIH}){ }^{268}$ When CellPro failed to obtain a license and was found liable for patent infringement, it petitioned for government march in. ${ }^{269}$ CellPro claimed both that the University and Baxter Healthcare Corporation, the ultimate sublicensee, had failed to take reasonable steps to achieve a practical application for the patented invention and that government action was needed to address health and safety needs not met by Baxter. ${ }^{270}$ The NIH, however, found that Baxter was taking reasonable steps to achieve practical application. ${ }^{271}$ The NIH also found that a health need existed, but that Baxter was reasonably addressing that need. ${ }^{272}$ Various parties expressed concern that exercising march-in rights in this situation would undermine existing licensing rights. ${ }^{273}$ Ultimately, the NIH declined to march in, due, at least in part, to overwhelming public opposition. ${ }^{274}$

The public opposition to the CellPro petition suggests that march-in rights are not an ideal solution to balancing interests in the gene patent debate. March-in rights raise concerns similar to those raised by compulsory licenses, namely that threatening or exercising march-in rights interferes with contractual freedom in the marketplace. ${ }^{275}$ Parties should be free to negotiate the terms of their license agreements, including the terms for terminating rights under the license. March-in rights eliminate this freedom. Furthermore, there are already natural

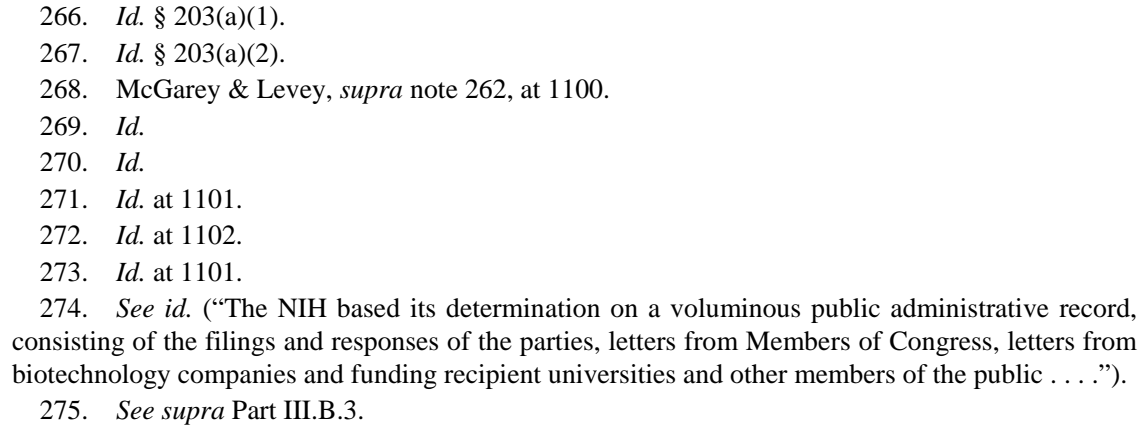

274. See id. ("The NIH based its determination on a voluminous public administrative record, consisting of the filings and responses of the parties, letters from Members of Congress, letters from biotechnology companies and funding recipient universities and other members of the public ....”).

275. See supra Part III.B.3. 
incentives for companies to voluntarily enter into license agreements. ${ }^{276}$ Indeed, a patent holder profits each time he licenses his invention. ${ }^{277}$ Threatening or invoking march-in rights against holders of gene patents, thereby interfering with the public's freedom to contract, is not a preferred solution to the gene patent debate.

\section{CONCLUSION}

Genes and diagnostic methods are patent-eligible subject matter under current patent law, and if the Supreme Court grants certiorari in Association for Molecular Pathology for a second time, it should continue to hold them as such. Courts can properly exclude claims undeserving of patent protection by ensuring the requirements of utility, novelty, nonobviousness, and adequate disclosure are met. Carving out genes as an additional exception to patent-eligible subject matter threatens far-reaching and unforeseen consequences. To balance the competing interests of incentivizing research and making genetic testing and treatment available and affordable to patients, Congress should enact a statutory research exemption that immunizes researchers from infringement liability for performing noncommercial activities involving the patented gene. Such congressional action would both encourage research and alleviate fear of lawsuits for patent infringement, thereby addressing several concerns of gene patent opponents. Enabling research on patented genes would allow nonholders of patents to confirm experimental results, enhance the quality of existing genetic tests, and promote further innovation involving the patented genes.

In contrast, Congress should view with caution suggested solutions like compulsory licensing or exercising march-in rights under the BayhDole Act. Such action seriously interferes with patent holders' freedom to negotiate and enter into contracts and will likely meet serious public opposition. These proposals overemphasize the desire to make genetic testing and treatment readily available, while ignoring the need to incentivize innovation and commercialization.

Ideal balancing solutions give appropriate weight to the need to incentivize biotechnology research. In discussing the importance of accessible and affordable genetic testing, it is important to remember that without patent protection the biotechnology research that lies at the heart

276. See supra Part III.B.3.

277. See supra Part III.B.3. 
of these discoveries might never have occurred. The genetic tests to which patients demand access would never have been developed. For this reason, any solution ultimately implemented must give fair consideration to the need to incentivize innovation within the biotechnology industry so that the public may continue to benefit from its efforts. 